catalase extracts from wheat which, unlike the crystalline enzyme, were not activated by the hydrogen peroxide substrate. P. V. Vittorio and G. Krotkov discussed the synthesis of sucrose and starch in detached tobacco leaves infiltrated with carbon-14-labelled glucose and glucose-1-phosphate. They concluded that the fructose moiety of sucrose arose from infiltrating glucose and not from free fructose, but that infiltrated radioactive sugars contributed only a small amount of their activity to starch.

D. E. Wells reported the discovery of Ascocybe, a new genus of primitive Ascomycetes, as a common saprophyte on wood, while M. Raymond described a noteworthy new hybrid between Eriophorum angustifolium and $E$. chamissonis. L. Butler summarized the results of an experiment with large and small strains of mice involving inbreeding and selection to increase the size of the former strain and decrease that of the latter. No effect of inbreeding on vigour was noted. In the large strain, experimental selection was neutralized by opposed effects of natural selection. In the small strain effects of natural selection were dominant, and bodysize actually increased in each generation.

In physiology and medical sciences, W. R. Campbell described a new method of photometric estimation of serum calcium, based on Schwarzenbach's reaction and promising routine rapidity and precision. F. T. English and R. L. Noble demonstrated that although either periodic acid or an aqueous extract of Lithospermum corceum may induce inactivation of human chorionic gonadotrophin in vitro, the mode of inactivation differs when judged by histological examination of the ovaries of treated animals. W. H. Cook and C. V. Luzena discussed ice propagation in model systems of solutions and membranes, in relation to the ability of living cells to survive freezing. Discontinuous behaviour is favoured by low membrane porosity, rapid cooling and increased concentration of solutes in the aqueous phase; supercooling and nucleation ahead of the ice front can be demonstrated in sucrose and gelatin solutions. C. A. Mitchell presented data indicating that at least two viruses can propagate themselves within the bovine mammary gland; resulting locally produced neutralizing antibodies may be found in both the blood and milk serum. J. Tuba and M. I. Robinson' reported that rat intestinal alkaline phosphatase consists of an adaptive portion varying with the dietary state and a non-adaptive fraction remaining constant even during prolonged fasting; the former is probably translocated lymphatically during fat absorption, thus elevating serum phosphatase levels. A. H. Hutchinson, V. H. Turnbridge and M. Elvin submitted photomicrographic evidence for mitosis, syngamy and meiosis in Bacillus subtilis (the cytological cycle being completed in two hours at $40^{\circ} \mathrm{C}$.), and compared the observed structural detail of euchromatic progression with the cytology of other forms. N. H. GRACE J. W. Hopkins

\section{New Fellows}

Six new fellows were elected to Section III : G. A. Adams, H. J. Bernstein, I. Halperin, M. Kulka, M. S. Macphail, J. S. Marshall ; four to Section IV : N. Campbell, Y. O. Fortier, J. W. Watson, L. J. Weeks; and six to Section V: J. A. Dauphinee, C. C. Heimburger, A. G. McCalla, J. H. Orr, J. H. Quastel, E. H. Strickland.

\section{PHOTOELECTRIC RAINDROP SPECTROMETER}

$\mathrm{D}$ ETERMINATION of the frequency distribution of the diameter of raindrops in relation to the rate of rainfall is an important problem of meteorological measurement. Knowledge of this distribution is important in the major scientific problem of the formation of raindrops and in such practical matters as protection of aircraft from ice accretion. Several methods have been used hitherto, such as measuring the size of the pellets formed when the drops fall into fine flour, the diameter of splashes on filter paper, or the magnitude of the noise produced when the drop hits a microphone. All had serious disadvantages, such as uncertainty of calibration or lack of flexibility in use in natural rain in which the rate of fall sometimes changes quickly.

Now, in the October number of the Quarterly Journal of the Royal Meteorological Society, B. J. Mason and R. Ramanadham, of the Department of Meteorology, Imperial College of Science and Technology, London, describe an entirely new apparatus - the photoelectric raindrop spectrometer-which is based on the scattering of light by the drops. A parallel beam of light of horizontal axis is produced, and the drops falling through a rhombus-shaped section in this beam of area $72 \mathrm{~cm}^{2}$ scatter light into the cathode of a photo-multiplier cell. The voltage produced by the light pulse is suitably amplified and recorded and the results interpreted from calibration with drops of known size. The apparatus has the great advantage that it records continuously and takes account without difficulty of obliquely falling drops and of changes in the rate of fall. The probability of two drops falling through the area in natural rain at the same time to give overlapping impulses on the recorder is so small that it can be entirely neglected.

A comparison of this new apparatus with older, more clumsy methods has shown very good agreement. A few records are given in the paper. A series taken during showers shows that the drop-frequency curve had two modes in the heavier rain. The rates of fall varied from $2 \cdot 43 \mathrm{~mm}$./hr. to $0 \cdot 22$ $\mathrm{mm}$. $/ \mathrm{hr}$. All had a mode of drop-diameter at $0.9 \mathrm{~mm}$.; the $0.22 \mathrm{~mm}$. $/ \mathrm{hr}$. rain had no second mode, and the second modes were $1.4 \mathrm{~mm}$. for the rate of $0.66 \mathrm{~mm} . / \mathrm{hr}$, and $1.6 \mathrm{~mm}$. for the rates of 1.26 and $2.43 \mathrm{~mm}$. $/ \mathrm{hr}$. The amount of rainfall recorded by a rainfall recorder over several minutes during a light shower and the amount deduced from the spectrometer readings agreed to within 5 per cent. The raindrop spectrometer is to be used in conjunction with a $3-\mathrm{cm}$. radar in the study of condensation processes.

\section{NATIONAL CENTRAL LIBRARY, LONDON REPORT FOR $1952-53$}

HE thirty-seventh annual report of the executive
committee of the National Central Library,
London, covering the year ended February 28, 1953,
records an increase in the Treasury grant-in-aid from
$£ 27,250$ during $1951-52$ to $£ 31,250$. The funds at the
Trustees' disposal were insufficient to cover the cost
of the essential reinforcements in the east wing of 
the building. 'The Carnegie United Kingdom Trust, when appealed to, made a special grant of $£ 7,500$, as

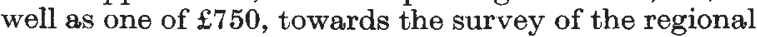
library systems and the National Central Library.

A joint working party, the terms of reference of which were expanded to include further aspects of inter-library lending, completed its work during the year, and its report was received by the executive committee in 1952, when the recommendations were submitted forthwith to the regional library executive committees for comment. A sub-committee of the joint standing committee on library co-operation has undertaken a project under which certain university and other libraries have agreed to co-operate, by purchases within certain periods of years, in filling gaps in British secondary or 'background' literature which is in increasing danger of being sold abroad. Returns have been made of several thousand holdings in many of the greater public libraries and university libraries.

Compared with 1951-52, issues of books from or through the Library increased by 1,105 to 99,413 , issues through university libraries and special outlier libraries increasing from 16,997 and 9,798 , respectively, to 18,040 and 10,198 , while those through municipal libraries and industrial and research organizations decreased, from 26,569 and 5,828 to 23,630 and 5,746, respectively. Total applications decreased slightly (from 101,383 to 100,049 ), but the percentage of applications handled successfully increased from $68 \cdot 27$ to $71 \cdot 21$. Issues from the Scottish Central Library increased from 15,708 to 16,349 and from the Irish Central Library for Students from 12,089 to 12,450 . Outlier libraries now number 225 and lent 24,478 volumes during the year. Books supplied by the regional system to other libraries in their own regions generally decreased, but university libraries, apart from loans under the national system, lent 23,905 books to other libraries during the year, compared with 21,965 during 1951-52. International loans also increased: 2,154 books were lent to 38 , and 1,026 books borrowed from 21, countries. Progress is also reported in the National Union Catalogue and the Union Catalogue of Russian Books and Periodicals, and the Sheaf Catalogue for German War-Time Books was completed.

\section{FORESTS OF THE BELGIAN CONGO}

TNER the title of "Forest Species and Timbers of the Congo" the Institut National pour l'Étude Agronomique du Congo Belge is publishing a monograph of which the first part has now appeared*. This part, which is an introduction to a study of the botanic and forest characteristics of species of the Congo forests, points out that Belgian forests alone can only supply a little more than half her timber requirements ; and as they are chiefly conifers they cannot provide for such necessities as construction and furniture, etc. Belgium has therefore to depend, in the same way as Britain, largely upon foreign markets, Scandinavian and United States, for the rest of her requirements. This has brought to the notice of a section of the public and to the Belgium Government that the Belgian Congo is one of the

- Publications de l'Institut National pour l'Étude Agronomlque du Congo Belge. Essences Forestière et Bois du Congo: Fascicule 1, Introduction. By Jean Louis and Joseph Fouarge. Pp. $72+15$ plates. (Brussels, 1053.) 180 Belg. francs. countries which possess the greatest areas of dense forests on the globe; for all the central part of the Belgian Congo is covered with the great equatorial forests of Central Africa, and these are estimated to amount to 125 million hectares, consisting of the diversity of species found in mixed tropical forests and representing, says the monograph, milliards of cubic metres of timber.

At first sight it would be asked why has this great source of timber wealth not been already drawn upon ? The answer, it is stated-and the British began to discover this for the tropical forests more than a century ago in India-is found in the inaccessibility of the forests, difficulties of exploitation, extraction and transport; but a start has been made. As was also found in India, there are difficulties in introducing new tropical timbers on the world markets, conservative timber merchants, architects and other users of timber being against such new importations.

The first question posed, however, is the necessity of knowing the botanic contents of the forests; and the second, whether a timber species of marketable value exists in sufficient abundance in a section of the forest to make its exploitation a commercial success. Also, as Bertin, a French forest officer of considerable African experience in the Ivory Coast and elsewhere during the First World War and after, said in his "La Question Forestière Coloniale" (Paris, Larose, 1919) : "Impossible de s'intéresser à des bois dont on ignore même le nom". It is considered, and probably correctly, that the Congo forests are not enough to provide for all the requirements of Belgium both in quantity and quality.

This monograph is being prepared with that object in view. It has the double purpose, botanic and forest, and will provide in subsequent parts a botanic and physical description of each species dealt with, followed by the mechanical and technological properties of the timber. In fact, much of it is on the lines of Gamble's "Manual of Indian Timbers" first published in the latter part of last century. This first part of the Belgian monograph is confined to general principles only.

E. P. Stembing

\section{MOTOR RESPONSES EVOKED BY THE DORSAL OCELLI OF SARCOPHAGA ALDRICHI PARKER, AND THE ORIENTATION OF THE FLY TO PLANE POLARIZED LIGHT}

\section{By Dr. W. G. WELLINGTON}

Forest Insect Laboratory, Sault Ste. Marie, Ontario

TT has been suggested that the dorsal ocelli of 1 adult insects are only stimulatory organs, capable of increasing any response to stimuli received through the compound eyes, but incapable of evoking a motor response by themselves ${ }^{1,2}$. Behaviour studies that support this view include those in which bees ${ }^{3}$ or ants ${ }^{4}$ acted as though blind when only their ocelli were uncovered, and those in which bees ${ }^{3}$ and Drosophila ${ }^{5}$ reacted more rapidly to sudden variations in light intensity when their ocelli, as well as their compound eyes, were uncovered.

Adult ocelli vary in complexity, and Wiggles. worth $^{6}$ has pointed out that their function may not 